\title{
Questão agrária, território e meio ambiente no Brasil: Os limites da transição para uma agricultura sustentável
}

\section{The agricultural, territorial and environmental question in Brazil: The transition limits for a sustainable agriculture}

\author{
Humberto Miranda-do Nascimento*
}

\begin{abstract}
This paper discusses the agrarian problem in Brazilian rural areas from the environmental point of view. The objective is to examine how the private appropriation of the Brazilian rural space came about, attributing to the environmental factor a role whose logic was relevant in the inherited agricultural context. According to this hypothesis, the specificity of the private appropriation process of public land, after 1850, is the origin of agricultural and environmental problems in the Brazilian rural space. We discuss how the market imperatives stimulated the undifferentiated degradation of the agro-ecosystems in terms of production scale. In the final considerations we emphasise the transition limits to a sustainable agriculture in the Southern region of Brazil.
\end{abstract}

Keywords: land appropriation, agrarian question, sustainable agriculture.

\section{Resumo}

$\mathrm{O}$ artigo discute o problema agrário em áreas rurais brasileiras sob o ponto de vista ambiental. O objetivo é examinar a forma como se deu a apropriação privada do espaço rural brasileiro, atribuindo ao fator ambiental um papel cuja lógica foi relevante para o contexto agrário herdado. De acordo com a hipótese, a especificidade do processo de apropriação privada de terras públicas, após 1850 , é o ponto de origem dos problemas agrário-ecológicos atuais no espaço rural brasileiro. Discute como os imperativos do mercado impeliram a degradação dos agroecosistemas, de maneira indiferenciada quanto à escala de produção. Nas considerações finais, enfatizam-se os limites da transição para uma agricultura sustentável na Região Sul do Brasil.

Palavras-chaves: apropriação de terras, questão agrária, agricultura sustentável.

*Universidade Católica do Salvador, Brasil. Correo-e: humbertomn@eco.unicamp.br. 


\section{Introdução}

O objetivo do artigo é examinar como se deu, historicamente, a lógica de apropriação privada do espaço rural brasileiro, atribuindo ao fator ambiental um papel relevante no contexto agrário. O processo de apropriação privada do território brasileiro deu o sentido à institucionalização do espaço rural, em termos gerais, enquanto um vazio social e ecológico e contra-face de sua ocupação econômica em favor do viés estritamente urbano de sua ocupação, num flagrante desequilíbrio socioespacial. Pode-se dizer que a ocupação do espaço rural brasileiro -tido como algo vago e inculto, desvalorizado social, cultural e ecologicamente-, além das contradições e conflitos oriundos da desigualdade no acesso à terra, promoveu a desigualdade no uso e no acesso a recursos e espaços naturais. Adverte-se que os recursos naturais referidos não são vistos apenas como os objetos da Natureza a serviço da atividade econômica estritamente; eles são espaços e recursos regulados pela Natureza e desigualmente usados e acessados pela Sociedade. No cerne desse uso-acesso desigual do território está a questão agrária.

$\mathrm{O}$ artigo, apesar de tratar da especificidade do caso brasileiro, pode contribuir para o entendimento crítico da relação entre questão agrária e ecológica no caso colombiano, a partir do estudo de Checchia (2007), no livro Terra e capitalismo: a questão agrária na Colômbia (1848-1853), e os estudos sobre a relação sociedade-natureza envolvendo as populações camponesas mexicanas nos trabalhos de Víctor Toledo, Leticia Merino-Pérez, Francisco Chapela, entre outros, bem como as implicações mais teóricas das análises de Martinez-Alier (1994 e 2007) e Enrique Leff (2006) sobre ecologia política camponesa. Por falta de espaço, optou-se para o estudo mais aprofundado do caso brasileiro, que possui uma numerosa população rural (pelos dados oficiais, cerca de 17.3 milhões estão ocupadas em atividades agropecuárias $^{1}$ ) e que conta com um considerável avanço na modernização de sua agricultura, sem que se tenha equacionado o problema agrário. Isto nos leva diretamente à hipótese aqui discutida: a transição para uma agricultura sustentável no espaço rural brasileiro passa não só pelo equacionamento da questão agrária, mas do problema agrário-ecológico.

${ }^{1}$ Instituto Brasileiro de Geografia e Estatística (PNAD-IBGE, 2006). 
A análise do processo agrário brasileiro se dará, todavia, a partir do entendimento das lutas sociais agrárias como lutas ecológicas pelo território, como ressalta Martinez-Alier (2007), sendo este território o lugar de reprodução da vida em sentido concreto, onde as interações humano-ambientais se realizam como um processo co-evolucionário, inseparável. Para investigar a questão ambiental na origem das transformações das áreas rurais no Brasil, dá-se um tratamento ao mesmo tempo histórico, político e institucional à questão ambiental com vistas a restabelecimento do sentido político-ecológico do problema agrário brasileiro contemporâneo. Trata-se, portanto, de entender o caráter das relações de propriedade no campo brasileiro, através de um processo aqui chamado de expropriação social e ecológica do território. Em resumo, a expropriação social e ecológica do território como corolário da apropriação privada de terras públicas. Mas qual a especificidade do caso brasileiro?

Considera-se que a instituição do espaço rural brasileiro obedeceu à lógica de valorização econômica do território com exploração extrema dos seus recursos e espaços naturais, dando a esse processo um caráter de ethos do progresso, só que limitado ao estabelecimento de uma "agricultura ilustrada" (Lourenço, 2001) em detrimento do desenvolvimento de uma agricultura nacional, como defendida já na transição do Império para a República pelo engenheiro e abolicionista André Rebouças, conforme assinala Pádua (2002). A questão, sob a ótica de Rebouças, é não perder de vista a perspectiva territorial da análise quando se fala em agricultura nacional. $\mathrm{Na}$ impossibilidade de implementar a "democracia rural", como defendia, o caráter itinerante da agricultura se tornaria uma marca específica do capitalismo agrário brasileiro. Por essa ótica, Cano (2002) salienta que:

Mesmo nas agriculturas de pequena propriedade [...] do Espírito Santo e do Sul do país, embora livres do jugo latifundiário, a dominação do capital mercantil teve forte presença, inibindo a introdução de doses maiores de progresso técnico e estimulando práticas degradantes da agricultura e, conseqüentemente, obrigando-a a também itinerar. Aqui, entretanto, a propriedade dos meios de produção permitiu níveis mais amenos de concentração de renda e melhores condições sociais (Cano, 2002: 119).

Embora o autor acima ressalte os "níveis amenos de concentração de renda e melhores condições sociais", o caráter itinerante da agricultura constituiu-se num elemento fundamental da 
formação do ethos progresista no capitalismo agrário brasileiro. Chama-se à atenção, nesta* interpretação, para a definição de um arcabouço histórico-institucional subjacente ao processo de apropriação privada de terras no território brasileiro, a partir de em Silva (1996, 2001) e Moraes (2005a, 2005b). Com isso, a preocupação do artigo é entender a itinerância como fator-motor da institucionalização do espaço rural, atuando na criação de um vazio social e ecológico à medida que avançava sua ocupação econômica.

A itinerância, como força indutora da degradação ambiental, estava alicerçada no padrão de ocupação do território, que se fazia com a contínua incorporação de novas terras ao cultivo e à posse. De acordo com Silva (1996), prevaleceu na atitude dos proprietários o consenso que foi se formando entre os juristas de que a lei de 1850 não obrigava sesmeiros e posseiros a regularizarem sua situação. Isto porque, segundo a autora, a alegação de "moradia habitual" e "cultura efetiva" garanti-los-ia nas suas terras (Silva, 1996: 216). Dessa maneira, a regra de degradar para itinerar, mantendo a ordem social e econômica inalteradas, justificava o processo anômico ${ }^{2}$ por meio do qual grassavam as formas de ocupação do espaço rural brasileiro.

Para Moraes, especialmente, o expansionismo do sistema de produção colonial no Brasil reiterava, em bases sólidas, a orientação central na estruturação ou construção nacional de seu território, reafirmando o caráter itinerante no plano político. Afirma:

Uma idéia-eixo que se vai perpetuar ao longo de nossa história é a de construir o País. Tal idéia tem por pressuposto uma ação colonizadora, isto é, a ocupação dos fundos territoriais não explorados vai ser alçada à condição de projeto nacional básico. Tal formulação serviu, primeiramente, para aproximar elites regionais desconectadas economicamente numa iniciativa política unitária, isto é, forneceu-lhes um cimento comum que os interesses econômicos imediatos não propiciava. Em segundo lugar, essa idéia em si mesma legitima a existência de um Estado forte e ativo, pois caberá fundamentalmente a ele a condução desse processo (Moraes, 2005a: 14).

Ao consignar a conquista territorial como marca da identidade nacional, herda-se do sistema de produção colonial uma ótica dilapidadora do espaço, pelo padrão expansivo, e dos recursos naturais, pelo padrão intensivo. "Nesse quadro, as populações (au-

${ }^{2}$ A idéia de anomia deve ser entendida aqui mais como uma discricionariedade na aplicação das leis do que da ausência de leis. 
tóctones ou transplantadas) são vistas como apenas um meio de se retirar a riqueza natural” (Moraes, 2005a: 14). Vem daí uma noção clara do autor do papel do Estado num país periférico:

O grande agente de produção do espaço é o Estado, por meio de suas políticas territoriais. É ele o dotador dos grandes equipamentos e das infraestruturas, o construtor dos grandes sistemas de engenharia, o guardião do patrimônio natural e o gestor de fundos territoriais. Por estas atuações, o Estado é também o grande indutor na ocupação do território. Um mediador essencial, no mundo moderno, das relações sociedade-espaço e sociedade-natureza. Tal qualidade ganha potência nos países periféricos, notadamente nos de formação colonial, como o Brasil (Moraes, 2005a: 140).

Porém, não se tinha uma visão clara, até 1930, no Brasil, do sentido de nacionalidade. Até porque apenas uma parcela modesta do território nacional estava extensivamente ocupada, de modo que o agrário, enquanto espaço de penetração de relações mercantis e de propriedade, entrou rapidamente em sincronia com a intensificação do processo concentração fundiária. Esta concentração fundiária tinha duas funções precípuas: tanto incentivou a modernização econômica quanto a degradação ambiental do território.

Por essa interpretação, o Brasil do século Xx vai experimentar grandes progressos na consolidação de um setor agrícola avesso à realidade sócio-ambiental do seu meio rural e voltado para o atendimento das demandas dos grandes proprietários de terras, especialmente os cafeicultores, que detinham o produto mais valorizado, mais rentável, do mercado internacional. Um processo marcado também pela institucionalização e aparelhamento de uma ciência e tecnologia agrícola, através da montagem de institutos de pesquisa e escolas de agronomia voltadas para a produção agrícola e pecuária em larga escala (Lourenço, 2001), a fim de que atendessem a volumes crescentes de grãos e crescimento da produção pecuária, ao mesmo tempo em que corroborava uma mentalidade rentista e progressista não-democrática. ${ }^{3}$

Esta situação perdurou e se ampliou no apogeu da Revolução Verde no Brasil, nos anos de 1970, especialmente, e que logo revelou ser um problema dramático a partir da década de 1980, quando o fim dos subsídios agrícolas precipitou as conseqüências mais perversas do modelo agrícola brasileiro, com crescente

${ }^{3}$ Isso gerou o que se pode chamar de uma antinomia entre o propriamente agrícola e o propriamente agrário, de acordo com o pensamento de Inácio Rangel. 
perda de recursos naturais. Se isto permitiu ao país construir uma agricultura moderna a expensas da degradação ambiental do território, impediu a construção de uma agricultura nacional calcada na democracia rural, com a incorporação do trabalho livre do ex-escravo na economia nacional, como preconizou Rebouças (Pádua, 2002).

Com base nesse referencial teórico, o presente artigo estrutura-se em três momentos. No primeiro momento, apresenta-se um breve contexto da evolução do debate em torno da questão agrária no Brasil. No segundo, interpretam-se as transformações no espaço rural brasileiro como conseqüência da apropriação privada do território, situando o problema sob o ponto de vista ambiental. No terceiro, ilustra-se a análise com o caso da Região Sul do Brasil, a partir do caso do Estado do Paraná, discutindo por que a maior democratização fundiária não necessariamente responde à perspectiva de transição para uma agricultura ambientalmente sustentável. Nas considerações finais, resume-se a principal contribuição deste artigo.

\section{Questão agrária como problema econômico e social}

Do ponto de vista da ordenação jurídica da propriedade privada, a Lei de Terras de 1850 no Brasil (ver Box I) foi o ponto de origem das controvérsias em torno da questão agrário-ecológica. Como afirmou Silva, "pode-se dizer que as 'distorções' sofridas pela lei de 1850 constituíram o processo de sua aplicação" (1996: 343). Os conflitos se tornaram a essência de sua implementação, pois as camadas sociais mais abastadas utilizaram-se de diferentes meios para acomodar o ordenamento jurídico a seus interesses. A Lei serviu de parâmetro para a regularização da propriedade da terra, porém, sem dificultar o apossamento; orientou as ações de diferentes esferas de governo na questão fundiária, porém, sem amainar os conflitos; ampliou o acesso à terra, porém, sem democratizá-lo; consolidou a moderna propriedade territorial, porém, sem resolver os contrastes sociais e prevenir os impactos ambientais; e, finalmente, contribuiu para instituir o espaço rural brasileiro, porém, sem estabelecer os limites ecológicos à expansão da sua fronteira interna.

Outrossim, deve-se ponderar que só é possível falar de instituição do espaço rural no Brasil a partir do estabelecimento da propriedade plena, já que a aplicação da Lei de Terras permitiu que se levasse adiante, e se intensificasse, o processo de ocupa- 


\section{Box I, Lei de Terras de 1850 no Brasil}

A Lei $n^{\circ} 601$ foi aprovada em 18 de setembro de 1850 pelo Senado, ainda no Império, e ficou conhecida como Lei de Terras. Sua regulamentação em 1854 criou os mecanismos de sua execução, através da Repartição Geral das Terras Públicas, que deveria "dirigir e organizar a medição, descrição e divisão das terras devolutas e propor ao governo quais as terras que deveriam ser reservadas para a colonização indígena e estrangeira, quais as destinadas à fundação de povoações, à venda e à marinha". Ela visava estabelecer uma política de terras com dupla finalidade: regular a posse irregular e estimular a migração. A única forma de aquisição de terra seria por meio de instrumento de compra e venda, o qual financiaria a vinda dos imigrantes. O que caracterizou a política de terras daí até 1930 foram as recorrentes prorrogações de novos prazos para o registro de terras, imperando a grilagem e a violência no campo. Dois conflitos, especialmente, marcaram o período, a revolta de Canudos, de 1893 a 1897 e a guerra do Contestado, de 1911 a 1916, contestando uma área que hoje pertence ao Estado de Santa Catarina, no Sul do Brasil. Há uma forte semelhança do caso brasileiro com o da Colômbia (Checchia, 2007). Lá, a Lei de Terras, também criada em 1850, fez parte da política de baldios, de orientação liberal, posto que, naquele ano, cerca de 75\% do território colombiano era composto por terrenos baldios, cuja maior parte localizava-se nas fronteiras inexploradas.

Fonte: Silva (1996) e Checchia (2007).

ção do território não apenas como um mero ato formal. No termo instituição, o que vem implícito é, sobretudo, a consolidação da nova regra de apropriação territorial, que, sob o manto da Lei, condicionou as transformações econômicas das áreas rurais à ausência de limites ecológicos e humanos na sua exploração. Reitere-se. Não se trata apenas de considerar ou desconsiderar os limites ecológicos e humanos, os quais ganharam um lugar subalterno na formação nacional, conforme assinala Moraes (2005a), mas de justificar a expansão econômica pela consciência da ausência desses limites. Assim, para progredir economicamente, a itinerância da agricultura passou a ser uma característica preponderante da própria modernidade agrícola e agrária.

No Brasil, houve uma evolução importante no debate acerca da questão agrária no seu sentido marxista clássico. Ela apresentou um quadro histórico com vida bastante longa, desde 1920, por meio, destacadamente, do velho Partido Comunista (PCB), findando praticamente com o golpe militar de 1964, com um grande número de seus defensores duramente reprimidos. Não se preten- 
de, todavia, afirmar que houve um início e um fim para a questão agrária brasileira, que ela pertence ao passado ou não é mais válida atualmente. Trata-se apenas da constatação de que a direção política que traçava o fio condutor desse debate foi derrotada por um regime político de exceção, que impôs um modelo assentado em ideais liberais estritos, fazendo com que a retomada do debate se desse em novas bases. ${ }^{4}$ Aliado a isso, outros setores políticos progressistas e do chamado campo popular, bem como a produção acadêmica, deram novos encaminhamentos ao debate.

Neste texto, adotamos o critério de Delgado (2001) para discernir os períodos em que os temas agricultura e desenvolvimento e questão agrária adquiriram contornos distintos. Foram pelo menos três períodos: do pós-guerra ao golpe militar de 1964, foi a fase áurea do desenvolvimentismo; entre 1965 a 1985, a fase da modernização conservadora da agricultura brasileira, dentro do contexto industrialização; e Pós-1985, a fase de estagnação econômica, de desmonte do padrão de modernização agrícola, de conversão às políticas liberais e do surgimento de novos atores sociais (sem-teto, sem-terra, etc.).

\subsection{Primeiro momento: pós-guerra a 1964}

Entre o pós-guerra e 1964, discutia-se o lugar do setor rural na economia e na sociedade em processo de franca industrialização, ora para que se ajustasse ao modelo seguido de substituição de importações, ora como promessa de um projeto explícito de política econômica. Nesse contexto, a emergência do tema da Reforma Agrária como "questão nacional” era disputado por três setores distintos: o Partido Comunista Brasileiro ( $\mathrm{PCB}$ ), os setores ditos progressistas da Igreja Católica e a Comissão Econômica para a América Latina (CEPAL). Vindo logo atrás, um quarto grupo, representando os não-defensores da Reforma, e de espectro ideológico oposto, liderado por Delfim Netto e Roberto Campos, cujo enfoque era industrialista e liberal-conservador.

Do lado dos setores politicamente progressistas da academia, destacam-se ainda as análises de Caio Prado Jr. (1960) e Ignácio Rangel (1961). O primeiro justifica a realização da Reforma Agrária brasileira naquele momento à possibilidade de elevar os pa-

${ }^{4}$ No campo da luta política propriamente dita, a questão agrária sofreu um forte revés em 1964 com a imposição da derrota às Ligas Camponesas, mas o debate volta nos anos de 1980 e permanece vivo com o Movimento dos Trabalhadores Rurais SemTerra (MST). 
drões de vida da população rural (foco na inclusão socioeconômica). O segundo concentrou-se nos problemas da superprodução e escassez de produtos agrícolas (dificultando o comércio exterior) e da superpopulação rural (refletindo em desemprego urbano), fazendo com que o setor agrícola ora não liberasse mãode-obra em quantidade necessária para a expansão dos outros setores da economia, ora liberasse em excesso, rebaixando os salários. Esse debate ficou conhecido como problemas propriamente e impropriamente agrários.

Um pouco mais tarde, viria à tona a problemática estrutural cepalina que foi expressa no caráter inelástico da oferta de alimentos vis-à-vis as pressões da demanda urbano-industrial, como parte do diagnóstico do Plano Trienal (1963-1965), que justificava a necessidade de mudança tanto na estrutura fundiária quanto nas relações de trabalho no campo.

Completando o quadro evolutivo, chama atenção a mudança de mentalidade da igreja católica sobre a importância da Reforma Agrária. Este debate ganharia corpo com a criação da Conferência Nacional dos Bispos do Brasil (CNBB) nas décadas de 1950 e 1960, quando o episcopado constatou que a aplicação da doutrina da igreja católica contrastava com uma realidade agrária perversa. Foi posta em prática uma nova doutrina social. Ocorre a denúncia da injustiça e da exclusão social, o que leva à igreja a obter importante influência política na época por ter inscrito na sua Doutrina Social o princípio da função social da propriedade, logo incorporado ao Estatuto da Terra (1964) e, mais tarde, à Constituição Federal (1988), atualmente em vigor.

Do lado dos setores politicamente conservadores, a proposição defendida por Delfim Netto considera refutável a tese cepalina da rigidez da oferta agrícola. Os economistas liberais defendiam a tese da resposta funcional da oferta agrícola às pressões da demanda, já que não consideravam a estrutura fundiária existente e nem as relações de trabalho no campo como questões econômicas relevantes. Para eles, não era uma questão política. Sendo assim, não havia razão para se realizar a reforma agrária, bastando que a agricultura cumprisse adequadamente suas funções, via o estímulo da política agrícola, dentro processo de desenvolvimento já em curso, isto é, liberar mão-de-obra para a indústria, gerar oferta de alimentos, suprir a indústria de matérias-primas, elevar as exportações agrícolas e transferir renda real para o setor urbano. 


\subsection{Segundo momento: 1965 a 1985}

O golpe de 1964, além de calar por meio da força o debate agrário mais amplo, sentenciou que o caminho proposto pelos economistas liberais era o que seria seguido. Caminho este que ficou conhecido mais tarde na voz dos economistas críticos pelas seguintes denominações: modernização sem reforma, modernização conservadora ou "modernização dolorosa". O Programa de Ação Econômica do Governo (PAEG), elaborado ente 19641966, pelos Ministros Roberto Campos (Planejamento) e Octávio Gouvêa de Bulhões (Fazenda), tinha como objetivo interpretar o desenvolvimento e formular uma política que eliminasse os estrangulamentos internos da economia que bloqueavam o crescimento. Para eles, a causa fundamental era a pressão inflacionária e somente a modernização do setor agropecuário surtiria efeito e não uma reforma. A Reforma só seria necessária se feita de modo pontual e, mesmo assim, onde a estrutura agrária, comprovadamente, gerasse ineficiência econômica, já que a expansão da agricultura dependia, segundo eles, de quatro fatores básicos: nível técnico da mão-de-obra; nível de mecanização; nível de utilização de adubos; e de uma estrutura agrária eficiente.

Tal modelo, além de ter imposto uma derrota política ao movimento social pela Reforma Agrária, ofereceu uma resposta política que priorizava a valorização do café e seu regime cambial favorável, que apressava a industrialização e a urbanização então em curso, diversificando e elevando consideravelmente as exportações agrícolas e agroindustriais. A adoção desse modelo teve ampla repercussão e contribuiu para a consolidar uma estrutura fundiária social e ambientalmente perversa, pois concentrava ainda mais a propriedade da terra e promovia a degradação ambiental do território.

\subsection{Terceiro e último momento: o pós-1985}

No pós-1985, com o fim do regime militar e a abertura política, o debate em torno da questão agrária foi retomado como dilema político. O ambiente político interno passou a ser de radicalização da democracia, principalmente com as grandes manifestações da sociedade civil por eleições diretas para presidente da república e, mais tarde, com os debates acerca da elaboração da Nova Constituição Brasileira. Da parte do ambiente econômico externo, consolidava-se uma nova ordem econômica mundial, 
com base em crescente endividamento dos países latino-americanos e radicalização das doutrinas liberalizantes. Nesse novo contexto, estavam de um lado os movimentos sociais, que voltavam a atuar com toda força e de outro, aumentavam as restrições ao financiamento externo da economia brasileira, agravando a situação social e política.

Os ativistas políticos e estudiosos, favoráveis à realização de uma ampla reforma agrária, consideravam que a temática agrária poderia se impor por pressão social. Porém, o que se constatou, segundo a visão de muitos deles, foi a consolidação de um dualismo no processo de desenvolvimento brasileiro, caracterizado pelo padrão de modernidade econômica de um lado e de atraso social de outro. Esse fato contribuiu fortemente para restringir o debate agrário à construção de alternativas ou de estratégias de desenvolvimento dentro do espectro da industrialização da agricultura, no que veio a ser chamado mais tarde de complexos agroindustriais (Graziano da Silva, 1996).

Delgado (2001), porém, classifica os anos de 1980, no geral, como um período de transição. Para ele, o Brasil passou do período modernizante-conservador para o liberalizante-conservador, o qual tomaria realmente forma nos anos de 1990. Essa transição a que se refere representaria uma nova inflexão no debate agrário. As razões apontadas pelo autor são de que: o cenário econômico foi de relativa estagnação industrial nos anos de 1980 e prosseguiu assim nos anos de 1990; a agricultura que gerou altos saldos comerciais externos, especialmente na década de 1980, encontrou um clima inverso nos anos de 1990, quando as exportações em geral sofreram revés acentuado, particularmente com a entrada em vigor do Plano Real (1994-95); o desmonte sucessivo do aparato estatal nos anos de 1980 e 1990, fez com que parte essencial das intervenções no setor agrícola, que vigoraram desde 1930 e foram recicladas pelo regime militar, deixassem de existir quase por completo; a falta de prioridade na política do desenvolvimento agrícola na agenda do Estado tornou-se fato consumado, motivada que foi, sobretudo, pela perda de impulso da própria industrialização; e a priorização do setor externo da economia no período recente foi, praticamente, a única política que restou do período modernizante-conservador.

Nesse sentido, o significado do debate agrário, de acordo com essa sintética periodização, a partir de Delgado (2001), foi bastante simplificado no que se refere ao papel do setor agropecuário, o que amesquinhou o caráter nacional do desenvolvimento 
brasileiro. A modernização agropecuária foi substancialmente robustecida, com a diversificação e aumento da produção, alterando o padrão tecnológico do setor, mas, ao mesmo tempo, mantendo inalterada a heterogeneidade social. O pacto agráriomodernizante-conservador apoiou e defendeu o latifúndio na sua nova estrutura fiscal e financeira, fazendo com que todos os ingredientes políticos que precipitaram o debate mais amplo em torno da questão agrária ficassem em compasso de espera, prontos para re-eclodir com mais força ainda nos anos de 1990.

Rezende (2003) destaca que, nos anos de 1990, a desregulamentação do mercado e a nova política de preços mínimos e crédito agrícola tornaram a estrutura produtiva do setor agrícola mais competitiva, tanto do ponto de vista interno e externo, o que resultou numa tendência geral de aumento da produtividade e redução de custos. Situação esta que marcou a retirada do governo como principal comprador em vários mercados. Além do mais, a sobrevalorização cambial do período 1994 a 1998 elevou o nível de exigência do setor agrícola em termos de competitividade, situação só amenizada após 1999, com a desvalorização cambial, a qual deu-lhe novo impulso ao recuperar a rentabilidade.

Garcia e Palmeira (2001), por sua vez, observam que o período recente é marcado pelo que chama de "dilema do enraizamento da modernidade", segundo o qual os pesos relativos do rural e do urbano para o desenvolvimento brasileiro são um legado da formação histórica do Brasil. Estes autores chamam a atenção, especificamente, para o processo em que o mundo urbano em expansão, ao mesmo tempo em que criava novas condições de vida, tinha seu dinamismo e seus rumos dependentes, em alguma medida, da reestruturação das formas de operar (fazer prosperar) o universo agrícola. Isto é, não se tratava simplesmente de superar uma tradição rural ou "superar seu atraso", como se diz vulgarmente, mas de como substituir um universo de relações sociais por outro sem que isso implicasse em maior empobrecimento e degradação ambiental. Ao invés disso, veio a justificação do atraso do mundo rural e não sua superação, com a acelerada urbanização brasileira não se constituído num processo civilizatório de fato, pelo contrário. As heterogeneidades sociais foram ampliadas, tanto no campo como na cidade.

Durante todo o ciclo de industrialização da economia brasileira, no período de 1930 a 1980, apesar de ter sido estabelecida uma rota clara guiada pelo modelo da substituição de importa- 
ções, ${ }^{5}$ o que se viu foi prevalecer um processo de urbanização como sinônimo de "cidades industriais", onde se criaria um universo de direitos e um processo de ruralização identificados com um universo de privações. $\mathrm{O}$ rural passou a ser tratado de modo subsidiário dentro modelo de industrialização, como um setor, o agrícola, cumprindo um papel funcional dentro da expansão da indústria brasileira.

Tratou-se, portanto, de demonstrar nesta seção como foi o encaixe do setor agropecuário no contexto da industrialização, a expensas do debate agrário e relegando o espaço rural à sua própria sorte. Mais que uma relevância estatística, o rural perdeu seu nexo socioespacial e, saliente-se, ecológico. Daí a proposta de retomar a visão do rural como base no nexo agrário-ecológico de sua conformação socioespacial, reinterpretando a origem do problema agrário brasileiro.

\section{Ecologia política agrária no Brasil: indo à raiz do problema}

De acordo com o que foi dito até o momento, considera-se a hipótese de que a questão ambiental está na raiz do problema agrário brasileiro. Isto é, a natureza do processo de apropriação privada de terras no Brasil teve na alienação/destruição da biodiversidade seu impulso econômico básico. Nessa condição, degradar para itinerar tornou-se a regra principal do desenvolvimento econômico moderno e politicamente conservador no espaço rural brasileiro, como já se afirmou anteriormente. Por esse ponto de vista, a insistência em denunciar a concentração fundiária e reivindicar a democratização do acesso à terra no Brasil, como condição sine qua non para se fazer justiça social, apesar de ser uma importante agenda dos movimentos sociais rurais na América Latina, não é por si mesma razão suficiente para garantir um verdadeira transformação nas relações sociais rurais, se não for levada em conta a dimensão ecológica do problema agrário.

Há pelo menos duas interpretações tradicionais no debate agrário brasileiro relativamente aos seus impactos ambientais sobre o território. A primeira considera que a estrutura agrária brasileira foi resultado da sua condição de colônia e pouco mudou de lá para cá, inclusive a prática da destruição dos recursos

\footnotetext{
${ }^{5}$ Oriundo da CEPAL, tal modelo foi concebido como um processo interno de desenvolvimento, estimulado por desequilíbrio externo, diversificação e crescimento do setor industrial.
} 
e espaços naturais. A segunda considera que a difusão do modelo euro-americano de modernização agrícola, mais conhecido como Revolução Verde, foi o promotor por excelência do start desencadeador dos problemas ambientais no meio rural brasileiro, tais como a erosão dos solos, a desertificação, o desmatamento, entre outros. Aqui se defende uma interpretação alternativa. Afirma-se que não se tratou simplesmente da permanência do oligarca rural tosco do período colonial, embora ele continuasse a existir como chefe político regional em firme aliança com o latifundiário empreendedor do café. Nem tampouco se tratou apenas do impacto da difusão, anos mais tarde, do "pacote" tecnológico da chamada Revolução Verde, fato que veio dar sentido à modernização conservadora. Na verdade, o ethos progressista estava dado pelas relações de propriedade e absorveria rapidamente cada pacote tecnológico que surgisse, reproduzindo reiteradamente a regra da degradação-itinerância.

Para o caso brasileiro, a regra citada acima se materializa na ausência de limites ambientais nas diferentes frentes de expansão da fronteira e ocupação do território via o processo de apropriação privada. Ocupam-se terras devolutas como "vazios" territoriais ou vazios ecológicos e sociais, instituindo o espaço rural enquanto regulação predatória do acesso à terra e condição de manutenção das relações de propriedade tais como são. Como discutido por Robert Brenner (1995), no seu artigo seminal "Agrarian Class Structure and Economic Development in Pré-Industrial Europe", no qual observa que a regulação predatória fez parte das regras de reprodução características do processo de apropriação privada de terras. No caso do Brasil, isso significa que a estrutura fundiária seria mantida pela modernização, funcionando como sua "regra de reprodução característica", através da qual, o vínculo entre o agrário e o ecológico é negado.

Foi nesse sentido que a modernização das relações de propriedade no espaço rural brasileiro foi possível sem que se rompesse totalmente com o legado da estrutura agrária herdada da economia colonial. Ao desenvolver uma agricultura em larga escala, baseada nas grandes plantações, o país precisou desse legado para desenvolvê-la na forma social capitalista específica, porque a situação de dependência estrutural do agro brasileiro em relação ao mercado externo, enquanto imperativo, exigiu-lhe isto. Conforme Silva (1996, 2001) e Moraes (2005a; 2005b), e este é um aspecto importante, a natureza das relações de propriedade no rural brasileiro se fez constituir politicamente, ou seja, não foi 
uma esfera econômica autônoma que comandou internamente esta exigência, foi o estabelecimento de forte aliança entre os grandes latifundiários e o Estado nacional, enquanto elite de poder, que as condições de instituição e manutenção de uma certa ordem econômica e social no campo foram criadas, com as précondições para a acumulação interna sendo forjadas, simultaneamente, a partir de São Paulo.

Afirma-se, portanto, que a instituição do espaço rural brasileiro se deu com base em relações de propriedade especiais que condicionaram a valorização econômica do território à exploração extrema dos seus recursos e espaços naturais, dando a esse processo um caráter de ethos do progresso, limitado à valorização de uma agricultura ilustrada (Lourenço, 2001) em detrimento do desenvolvimento de uma agricultura nacional (Rebouças, apud Pádua, 2002). Isso impõe que se reveja ou reinterprete o processo de modernização do modelo agrícola, a partir da difusão da Revolução Verde no Brasil, como principal fonte de explicação para a progressão da degradação ambiental no território. Na perspectiva adotada neste artigo, logo no início do século Xx, já havia um ambiente propício à difusão e absorção de novas tecnologias up to date, sem romper necessariamente com um legado de destruição ambiental.

É claro, assinale-se, que a adoção dos princípios da Revolução Verde, após a década de 1960, até pela escala em que se deu, teve uma influência decisiva na generalização da degradação ambiental e deterioração social do espaço rural brasileiro. O que se chama atenção, no entanto, é que, do ponto de vista das relações de propriedade vigentes, foi a permanência estrutural da monocultura de fronteira aberta quem, de fato, levou ao paroxismo o processo de degradação ambiental e deterioração social do território. Processo reforçado pela expulsão de pequenos lavradores e reprodução de outras levas de pequenos e médios proprietários rurais, bem como do fracionamento de grandes propriedades nos períodos de perda de rentabilidade das lavouras tradicionais. Após o esgotamento de cada ciclo expansionista da fronteira agrícola, e à medida que outro ia se impondo, os vínculos entre o agrário e o ecológico iam se destruindo. Nesse sentido, a concentração fundiária teve na profusão de minifúndios rurais com alguma alternativa de sobrevivência sua contra-face, mas sem gerar ou garantir efetivamente novas oportunidades econômicas para a maioria da população rural. 
Se a Lei de Terras de 1850 ajudou, por um lado, a pavimentar o caminho através do qual os atores sociais em conflito vão transitar para um novo regime de propriedade, por outro lado, ela, por si só, não ajuda a explicar o desencadeamento do processo de apropriação privada. É preciso explicitar quais especificidades geraram as condições necessárias para isso. A difusão da apropriação privada de terras devolutas, como algo vazio e inculto (Silva, 1996), foi uma condição, pois condicionou toda forma de apropriação do território, produzindo vazios ecológicos $e$ sociais. Pode-se dizer que a Lei de Terras foi o ponto origem, mas somente a continuidade das formas predatórias de exploração dos espaços e recursos naturais no Brasil, através da monocultura em fronteira aberta, foi que selou o compromisso central com a modernização agrícola socioambientalmente predatória no país. É nesse sentido que fator ambiental adquire um caráter estruturante nas relações de propriedade perpetuadas no espaço rural brasileiro, o que redefine o problema agrário.

Para argumentar, considera-se que nem as mais diversas tecnologias agrícolas empregadas conseguiram promover a contento um progresso material mais amplo, tendo em vista a intensidade da exploração dos recursos naturais, e nem foram um impedimento para a ocupação extensiva do espaço agrário brasileiro. Isso se deu por três razões básicas: pelo aperfeiçoamento dos mecanismos de controle político de certos grupos de interesse sobre a ação do Estado, pela consolidação da influência do poder econômico dos latifundiários-empreendedores do Estado de São Paulo e pela eclosão continuada de conflitos agrários. Para corroborar tal argumento, pode-se citar o caso da Europa, onde havia dificuldades em se praticar a monocultura total, devido à menor oferta de solos férteis e ao grau acentuado de desgaste do solo, conforme Romeiro (1998). No Brasil, a condição de fronteira aberta (ou móvel) permitia um ajuste maior a esse sistema e anulava os efeitos do aumento dos custos da degradação ambiental sobre a exploração agrícola. Daí as tecnologias e os pacotes tecnológicos se adequarem bem à realidade rural do país sem maiores consideração do fator ambiental.

De acordo com Romeiro (1998), a monocultura foi referendada na Inglaterra por uma lei, The Agricultural Holding Act, de 1909, que "eliminou os últimos empecilhos legais à prática da monocultura ao tornar sem efeito as antigas normas sobre o método de cultura contidas nos contratos de arrendamento". Ademais, o desenvolvimento histórico particular que caracteri- 
zou o século xx, em especial, com a realização de duas guerras mundiais, foi decisivo nos rumos da difusão do padrão agrícola dominante, sobretudo, com o advento da Revolução Verde, cuja característica principal foi a simplificação dos métodos de cultivo e sua difusão para diversos países do globo, inclusive as regiões tropicais.

Levando-se em conta apenas o caráter da difusão do modelo euro-americano de modernização agrícola, pode-se até objetar o ponto de vista aqui desenvolvido, reclamando que toda a perspectiva adotada neste texto não definiu claramente o que de fato é o agrário. Este é um aspecto importante da reflexão já que o problema agrário não é e nem deve ser visto separadamente do fator ecológico. O que se argumenta, reiterando, é que o elo entre agrário e o ecológico foi negado durante muito tempo e precisa ser posto no centro do debate sobre desenvolvimento rural. Mais correto seria dizer que a análise das áreas ou regiões rurais deveria levar em conta as transformações agrário-ecológicas em seu conjunto e, no plano social das lutas agrárias, o conflito agrário-ecológico oriundo destas transformações. Chama-se de agrarismo ecológico a forma como as lutas sociais agrárias se transmutaram em lutas ecológicas pelo território. Portanto, não se trata apenas de definir o agrário, mas de explicitar o fator ambiental, definido pelos efeitos da degradação sobre o território e entender a dimensão ecológica, definida pela valorização do conteúdo socioespacial e natural do território na estruturação e reconfiguração das áreas rurais ao longo do tempo.

Pelo lado das transformações agrário-ecológicas, a abordagem da economia rural pode enriquecer-se com os temas da ecologia política agrária, aprofundando-se no estudo das transformações no acesso-uso dos espaços, recursos e serviços naturais causadas associado ao avanço dos processos agrários, que se dão via ampliação dos mecanismos de regularização fundiária ou do crescimento das atividades agropecuárias em seu conjunto.

Muitos dos conflitos sociais podem ser expressos como lutas ecológicas e para que isso ocorra é preciso tornar visível seu conteúdo. Nos territórios engendrados pela agricultura camponesa são reveladas as mais diversas linguagens da consciência ecológica radical, que se traduz em simbologias próprias dos problemas concretos. Cabe aos movimentos sociais rurais tornar visíveis muitas das "externalidades ambientais" causadas pelo funcionamento do sistema econômico. Sintomas de problemas ambientais são observados em situações sociais nas quais, por 
exemplo, o homem e a mulher camponesa são privados das condições materiais e subjetivas de interação entre o território e a natureza. Quando tais condicionantes estruturais e subjetivos não lhes proporcionam melhores condições de desenvolvimento, então, emergem conflitos destruidores dessa interação. $\mathrm{O}$ movimento social, porém, não deve apenas denunciar essa situação, ele deve estabelecer o front de sua luta em torno de uma questão específica: a luta pelo acesso à terra passa a não ser somente uma luta por um ativo econômico, mas uma luta ecológica pelo território.

A discussão acima ajuda a entender como as lutas sóciais no campo podem ser definidas pela participação na construção de uma territorialidade específica camponesa (ruralidade), indo mais além da ocupação da força de trabalho familiar pura e simplesmente. Isso não quer dizer que esta ocupação não seja importante. É. Só que ela, sozinha, não define a filiação social do agricultor com o território, como dado cultural e muito menos como questão política nacional. Os movimentos sociais rurais favoráveis à agroecologia, por exemplo, buscam reforçar as características simbióticas do conservacionismo ecológico das populações rurais (Toledo, 2002), como defesa de direitos ancestrais atualizados e atualizáveis. Segundo Toledo:

Tras tres décadas de investigación agroecológica y etnoecológica, existe ya un respetable repertorio de ejemplos mostrando cómo el minifundio familiar (campesino o indígena) resulta mucho más eficiente desde el punto de vista del uso y conservación de los recursos naturales (suelo, agua, biodiversidad, energía, ecosistemas). La explicación es bastante simple y puede seguir varios caminos. Una propiedad grande no permite de entrada el manejo meticuloso y fino que requiere un uso ecológicamente apropiado (por ejemplo, la delicada variación de los suelos queda suprimida en las grandes extensiones o la manipulación de cultivos múltiples o el control biológico de las plagas). (2002: 30).

Assim, em sua interação primordial com a natureza, as populações realizam a reposição e recomposição intergeracional da base de conhecimentos locais sobre o manejo de espaços e recursos naturais e isso explica o por quê de a agrobiodiversidade camponesa não separar o agrícola e o silvestre, pois o input de genes silvestres é contínuo dentro da agricultura tradicional; e não separar a diversidade cultural e a diversidade natural, pois o sistema tradicional de variedades de sementes encerra ao mesmo tempo, em si mesmo, valor de uso, de opção e de existência (Martinez-Alier, 1994). 
Así pues, el incipiente movimiento ecologista popular relacionado con la biodiversidad agrícola plantea dos cuestiones: el reconocimiento (y discutiblemente el pago) de los derechos de los agricultores sobre los recursos genéticos por ellos conservados y mejorados in situ; en segundo lugar, el acceso en condiciones faborables, posiblemente gratis, a las variedades conservadas y mejoradas ex situ, con el argumento de que los materiales genéticos originarios provienen de la agricultura tradicional y que nada se ha pagado por ellos (Martinez-Alier, 1994: 135136).

O que se entende aqui por agrarismo ecológico são as percepções construídas pelos agricultores na luta pela reapropriação do território, incluída a reapropriação da Natureza (Leff, 2006). Quando o que está em jogo são os direitos dessas populações sobre os recursos genéticos que mantiveram durantes anos, com ou sem melhoras in situ e ex situ, deve-se considerar as condições materiais em que muitas delas se encontram, especialmente as rurais, ou seja, privadas das condições de desenvolvimento pleno.

O problema fundamental dos sistemas de produção agropecuário em grande escala é sua redundância em termos do uso de materiais e energia, ou seja, a dependência quase obrigatória de insumos químicos para manter a fertilidade do solo e o controle de pragas acaba por elevar ao máximo o duplo custo econômicoecológico de mantê-lo, resultando em ineficiência energética e em custos sociais perversos e duradouros. As estratégias da agricultura familiar fortemente vinculadas ao mercado de commodities tradicionais criam um risco sério à manutenção dos sistemas agrários onde perdura a agrobiodiversidade camponesa.

\section{Apropriação de terras e democratização do espaço rural no Sul do Brasil}

No contexto da América Latina, o texto clássico de Chonchol (1996), Sistemas agrários em América Latina, já chamava atenção para o tratamento marginal dado, até então, à agricultura camponesa ou familiar pelos estudos históricos e econômicos, especialmente no que concernia às lutas por terra dos camponeses e às características próprias da economia camponesa. Uma primeira característica é a de que a economia camponesa baseiase fundamentalmente no trabalho familiar, sendo a família o núcleo essencial de produção e consumo. Outra característica fundamental é a sua forma variada de posse da terra: 
Las formas de tenencia de la tierra, estas familias muestran una grande variedad de situaciones: propietarios individuales de pequeñas extensiones, arrendatarios, aparceros o medieros, colonos poseedores de tierras de frontera, miembros de comunidades indígenas, ocupantes precarios sin títulos de dominio, asignatarios beneficiados por reformas agrarias, etc. (Chonchol, 1996: 410)

$\mathrm{O}$ autor salienta que estas características reforçaram os elementos que diferenciavam a agricultura campesina ou familiar, tanto no que se refere à variedade de tamanhos da propriedade ou da unidade familiar, à ocupação maior ou menor da força de trabalho familiar, à riqueza de seus recursos naturais e seu potencial produtivo, aos seus padrões tecnológicos próprios e ao grau de integração com o mercados. Tais elementos dão uma territorialidade especial à agricultura familiar, permitindo-lhe localizar suas unidades próximo aos grandes centros urbanos, zonas mais distantes de fronteira, regiões montanhosas, vales de rios, regiões semi-áridas, etc. Todavia, as estratégias de sobrevivência da agricultura familiar -as quais foram historicamente constituídas- buscaram enfrentar, também de forma original, o processo de modernização agrícola, o qual cria limites à sua reprodução social e sustentabilidade dos seus recursos naturais.

O contexto no qual despontou a agricultura familiar da Região Sul do Brasil é um exemplo desse enfretamento que se dá, mesmo prevalecendo uma outra lógica de apropriação privada terras no território nacional. As circunstâncias históricas engendradas naquela região possibilitaram uma diferença essencial na estratégia de reprodução socioeconômica do agricultor familiar brasileiro: sua resistência social, a luta pela terra, fez com que ele forjasse a si mesmo e às suas condições de existência e reprodução socioeconômica tornando-se um ator social relevante na instituição do espaço rural da Região Sul do Brasil.

Delimita-se, ao menos, em quatro períodos o processo de instituição do espaço rural na Região Sul do Brasil: desenho territorial, desempenho agropecuário, combate à degradação dos solos e consolidação dos principais atores sociais. O primeiro período é marcado pela organização social e produtiva do território a partir dos núcleos coloniais em resposta ao desabastecimento regional, decorrente da desestruturação do sistema colonial, nos anos de 1870 e 1900; o segundo período é marcado pelos conflitos entre posseiros e empresas colonizadoras, pela política oficial de colonização e pela ascensão de um novo ator, o agricultor familiar, nos anos de 1910 e 1950; o terceiro período é marcado 
pela intensificação do processo mecanização agropecuária, forte crescimento agrícola, êxodo rural e agravamento da degradação dos solos, nos anos de 1960 e 1980; o quarto período é marcado pela política de combate à degradação dos solos e de fortalecimento da agricultura familiar, nos anos de 1990 e 2000.

O advento da República no Brasil em 1889 deixou indefinida a participação do governo federal no processo de colonização interna e os governos estaduais e municipais deixaram o movimento de ocupação com a iniciativa privada. Já os interesse da agricultura de exportação continuaram nas mãos da aristocracia açucareira (Região Nordeste) e dos cafeicultores (Região Sudeste) e em estreito vínculo com o desempenho do Estado, que se esmerou em atender os interesses destes setores. Nesse contexto, o Rio grande do Sul, província localizada na região Sul do Brasil, constituiu-se uma exceção.

O fato de ser uma província que atraía mais a atenção das correntes imigratórias levou os possuidores de terras a se interessarem mais pela legalização de suas propriedades. Naturalmente, a diferença com São Paulo reside no fato de que ali a imigração se dirigia para os núcleos de pequenas propriedades e não para a chamada colonização particular (Silva, 1996: 200).

Mas, tal exceção, não significava um rompimento com a regra geral do processo de apropriação territorial. Apesar da política de terras ser implementada a partir de mecanismos e instrumentos estaduais, são as regularidades do processo que interessam. Havia, segundo Silva, três fenômenos que imprimiam características fundamentais à apropriação de terras no Brasil: 1) a rápida adaptação da Lei de Terras aos interesses dos posseiros, que pressionavam pela dilatação dos prazos de legitimação da posse da terra, com a anuência de praticamente todos os governos estaduais até o final da Primeira República, em 1930; 2) o agravamento da apropriação de terras públicas, por meio da ocupação e invasão, promovida por posseiros, sem que houvesse qualquer tipo de coerção por parte dos poderes públicos; e 3) a emergência do coronelismo -e seu corolário, a violência no campo- como característica principal da passagem das terras de domínio publico (devolutas) para o domínio privado. Dadas regularidades do processo de apropriação privada, pode-se entender a especificidade da dinâmica de ocupação territorial de um dos três estados (Rio Grande do Sul, Paraná e Santa Catarina) da Região Sul do Brasil, o Estado do Paraná, que internalizou no seu 
território boa parte do processo de expansão da cafeicultura de São Paulo.

\subsection{Economia rural do território paranaense}

Observando o ciclo madereiro-cafeeiro no Sul do país não se terá dúvidas sobre as marcas indeléveis, tão profundas quanto duradouras, deixadas no espaço rural paranaense, desequilibrando o balanço econômico-ecológico do território. Entrando pela região Norte do Paraná, o café paulista ocupa toda a região nordeste do estado, o Norte Velho, lá pela segunda metade do século dezenove, começando pelas terras ocupadas pela Companhia de Terras Norte do Paraná, seguindo pelas margens do rio Paraná, onde se localizavam as terras mais férteis. Essa região era praticamente um prolongamento da economia cafeeira paulista.

A expansão da economia cafeeira paulista atingiria importante área do Paraná somente após 1930. Nesse momento, algumas condições econômicas já estavam dadas. Segundo Cano (1998):

De 1886 a 1913 -descontados 1897 a 1904, de crise- nasce a indústria em SP. Altas margens de lucro no auge cafeeiro e moderadas na crise (devidas à alta produtividade das zonas pioneiras) permitiram alta taxa de inversão na indústria, superando largamente a do restante da nação. Em 1900 compreendia 13\% da população nacional e em 1907 abarcava $16 \%$ da produção industrial, cifra que saltaria para $31 \% \mathrm{em}$ 1919 e para 45\% em 1939 (Cano, 1998: 58).

A tendência do desenvolvimento nacional é de concentração industrial no Sudeste do país, especialmente em São Paulo, onde as relações de propriedade politicamente constituídas entre o latifundiário-empreendedor e o Estado bancaram os serviços de migração. Havia amainado o fluxo de migração espontânea para os Estados Unidos e Argentina e uma parte substancial de imigrantes, a maioria de italianos, instalou-se naquele estado; outra, em menor contingente, foi para os estados do Sul trabalhar com agricultura. Todavia, não era estritamente a produção agrícola que diferenciava o Sul. Na verdade, após 1850, os efeitos da transição para o trabalho livre geraram desabastecimento regional de alimentos.

No Paraná, a população dedicava-se preferencialmente à extração da erva-mate e ao criatório nos Campos Gerais, Guarapuava e Palmas. Com a compra de inúmeros escravos por parte dos cafeicultores de São Paulo, o Paraná, tradicional esportador de farinha de mandioca, 
passou a ser importador. A partir de 1852, os preços dos alimentos chegam a subir 200\%. (Wachowicz, 1995: 143).

As colônias de Blumenau e Joinville tiraram proveito da subida dos preços obtendo uma valorização no preço dos seus produtos, o que estimulou os paranaenses a apostarem em projetos de colonização eles mesmos. Na região do Vale do Ribeira, ainda no Paraná, foi criada em 1859 a colônia Assungui, organizada em regime de pequena propriedade, distante dos caminhos dos tropeiros e da capital, Curitiba.

As terras da região do Assungui eram realmente férteis, mas a colônia não foi dotada de uma infra-estrutura adequada. Nos primeiros anos, os celeiros encheram-se de cereais colhidos. Mas, nem uma estrada razoável foi providenciada para comunicar a colônia com algum centro urbano, no caso Curitiba ou Antonina. Para a capital apenas um caminho de tropas foi providenciado. Em conseqüência, os cereais produzidos deterioravam-se nos celeiros por falta de transportes para os grandes centros consumidores (Wachowicz, 1995: 144).

Esse fato ameaçava a permanência dos colonos, a única força de trabalho disponível na região para a produção de alimentos. Assim, em 1875, a necessidade de investimentos em infra-estrutura (estradas, principalmente) fez o então governador do Paraná, Adolfo Lamenha Lins, investigar as razões do fracasso da colônia Assungui e avaliar o funcionamento de outras. Isso permitiu que se delineasse toda uma estratégica econômica baseada na criação de núcleos coloniais com vistas ao abastecimento regional. Segundo a proposta do governador: as colônias deveriam ser situadas próximas aos centros consumidores e localizadas em terrenos contíguos às estradas principais, e, em alguns trechos, às vicinais; o poder público evitaria falsas promessas aos imigrantes e facilitaria o acesso ao transporte; os lotes de terra ficariam na vizinhança de centros populosos e comunicáveis entre si por rodagens; o poder público garantiria o acesso facilitado à terra e daria um auxílio financeiro para compra de utensílios e sementes; depois de fixado à terra, o colono seria empregado na construção de estradas para manter a família; a colônia mais afastada da capital teria escola e capela; haveria facilidade de escoamento da produção agrícola pela proximidade do mercado urbano, contribuindo para que incrementasse a renda e assim quitasse o valor da terra com o governo; e as novas gerações seriam orientadas a ocupar o interior para evitar que se urbanizassem rapidamente. Com isso se resolveria o problema do abas- 
tecimento interno. A conseqüência imediata foi a criação, de 1875 1876, de mais núcleos coloniais no entorno de Curitiba e inclusive no litoral, contribuindo para atração de imigrantes.

Dez anos mais tarde, entre 1885 e 1886, Alfredo d'Escragnolle Taunay, então presidente da província, deu um passo ainda mais largo, constituiu inúmeras Sociedades de Imigração nos municípios do interior, a fim de estimular as correntes migratórias e colonizadoras para o Estado. Ao lado disso, explodiram os conflitos em torno de disputas territoriais (Questão de Palmas) entre Brasil e Argentina que iriam mudar processo de fundação e localização de núcleos coloniais. Começaram a fundar colônias militares e a nacionalizar a organização e o ordenamento territorial daquele espaço. Outros conflitos (revolução federalista gaúcha, em 1885) e disputas por porções do território (Questão do Contestado) entre os estados do Paraná e Santa Catarina influíram também, acentuando a criação de novos núcleos coloniais federais.

Foi nos primeiros anos século xx que houve a concessão de terras devolutas governo do Estado a companhias inglesas e argentinas, a fim de explorarem tanto a erva-mate quanto a madeira. Elas organizaram a colonização utilizando-se dessa população existente, que conhecia a mata e servia-lhes de mão-de-obra barata. Como não era necessário assalariar uma população que já tinha por hábito consumir a erva-mate, o pagamento era feito por cotas-parte proporcionando bons lucros às companhias. Com a vinda dos capitais de origem inglesa e norte-americana vinculados ao setor ferroviário para o Sudoeste do Paraná, uma forte economia madeireira local foi estruturada e sua produção industrial para exportação foi facilitada, a partir dos anos de 1940. Esta é uma característica marcante de uma economia que atende a ciclos de fronteiras agrícolas de expansão, com a produção de erva-mate sendo sucedida pela de café.

O mercado externo impele, dessa forma, a expansão da fronteira e transforma as áreas rurais paranaenses. O ciclo madereiro-cafeeiro deixará marcas indeléveis tão profundas quanto duradouras no espaço rural paranaense. Da região Norte do Paraná, o café paulista ocupa toda a região nordeste do estado (o Norte Velho) lá pela segunda metade do século XIX, começando pelas terras ocupadas pela Companhia de Terras Norte do Paraná, seguindo pelas margens do rio Paraná, onde se localizavam as terras mais férteis. Esta região era praticamente um prolongamento da economia cafeeira paulista. 
Ocorre uma outra ruptura nesse processo de ocupação econômica na primeira metade do século xx. A colonização era dirigida por duas companhias, uma japonesa e outra inglesa, que se associam à ação do governo do estado para ocupar terras devolutas, dividindo a terra em pequenos lotes, o que permitiu receber número acentuado de migrantes. A produção estadual que era de 1,1 milhão de sacas de café em 1946-1947 passa para 20.7 milhões em 1959-1960, superando São Paulo como maior produtor. Em que pese esse salto econômico do Paraná na economia cafeeira, vale dizer que São Paulo, nesse momento, tem na indústria pesada sua maior pujança, dando a esse fato importância relativa, pois será sua renda urbana que absorverá parte considerável da produção paranaense, fato que sem dúvida contribuiu para sua expansão cafeeira. Vemos, assim, que o Paraná se enquadra perfeitamente na dinâmica econômica dominante do centro-sul do país, correspondendo às regularidades do processo de modernização econômica.

Na década de 1960, o Grupo Executivo de Terras para o Sudoeste do Paraná (GESOP) regulariza a titulação das terras e passa a controlar as serrarias clandestinas, cobrando taxas para iniciarem um horto florestal e o reflorestamento (Steca e Flores, 2002: 87). O novo processo de ocupação da região se impôs, resistindo ao poder das colonizadoras, que eram favoráveis à continuidade do latifúndio rural. A instituição do espaço rural paranaense, diferentemente de outras regiões, vai contar com a participação de novos atores, que ajudam a democratizam o acesso a terra. Podese dizer também que toda uma extensão territorial que vai do Oeste de Santa Catarina ao Sudoeste e parte do Oeste do Paraná experimentou, de 1900 a 1960, toda sorte de transformações: demográfica, social, política, ambiental e territorial. Criou-se uma população homogênea com base no regime de média e pequena propriedade.

Pela lógica de apropriação privada dos territórios rurais do Sul, os interesses associados do Estado com os do capital estrangeiro prevaleceram e visavam a ocupação das regiões de fronteira. Depois de receberem terra como doação, muitas empresas colonizadoras ocupavam, desmatavam, loteavam e vendiam as terras aos colonos trazidos pelos governos estaduais. Legitimouse a mesma lógica de preencher 'territórios vazios', baseada numa concepção de fronteira que exclui o elemento nativo, tanto o homem quanto a natureza, mesmo diferenciando-se no que concerne ao papel da pequena agricultura. E o fato de se ter um 
acesso mais democrático à terra nessa região não significou que houve um grau menor de degradação ambiental, o que se discutirá a seguir.

\subsection{Processo de colonização e apropriação territorial no Sudoeste do Paraná}

Os interesses capitalistas estrangeiros entre 1900 e 1920 fizeram com que houvesse um rápido crescimento populacional nas áreas compreendidas entre as províncias de Santa Catarina e Paraná devido à atração exercida pelas companhias Brazil Railway Co. e pela Southern Brazil Lamber \& Colonization, concessionárias de amplas extensões de terra.

A Lumber construía ramais ferroviários que adentravam as grandes matas, onde grandes locomotivas com guindastes e correntes gigantescas de mais de 100 metros arrastavam para as composições de trem as toras, que jaziam abatidas por equipes de turmeiros que anteriormente haviam passado pelo local. A exploração industrial da madeira criou sérios prejuízos para a coleta da erva-mate e a subsistência de muitas famílias caboclas. Quando o guindaste arrastava as grandes toras em direção à composição de trem, os ervais nativos e devolutos do interior das matas eram 'talados' por este deslocamento (Machado, 2004: 151).

Vale mencionar que a implementação do empreendimento ferroviário na região requereu uma exploração econômica rentável da madeira, a fim de garantir o retorno dos investimentos privados. O problema foi o modo como isso ocorreu, descrito acima por Machado, perpetuando o legado da deterioração socioambiental do território. A Companhia Lamber, por exemplo,

Deixou como herdeira a empresa Cia. Brasileira de Viação e Comércio (Braviaco). Os negócios da Brazil Railway também incluíam exploração de madeira, assim como a Southern Brazil Lamber and Colonization Company, que a partir de 1908, atuava na colonização (exploração de terras) e extração de madeira. (Wachowicz, 1984 apud Steca e Flores, 2002: 68-69).

A Braviaco era ligada aos grandes proprietários de terras que, por sua vez, pertenciam ao grupo político dominante que governava o Paraná. Com o intuito de construir um ramal que ligaria Guarapuava à linha São Paulo-Rio Grande do Sul, o Estado cedeu imensas glebas de terra. Uma delas, a gleba de Missões, chegou a ter 425,731 hectares. Após 1930, o novo governo torna nulos e sem efeito os títulos de domínio expedidos. Em 1943 foi 
criada a Colônia Nacional General Ozório (Cango) nas terras da gleba das Missões. Segundo Wachowicz (1995: 182), o objetivo da criação da Cango foi atrair o excedente de mão-de-obra agrícola do Rio Grande do Sul para o Sudoeste do Paraná, em função da criação do Território Nacional do Iguaçu naquele mesmo ano. O número de famílias que a Cango abrigou foi de 467 em 1947 e 2,725 em 1956.

Disputas judiciais surgiram de disputas políticas em torno das glebas, envolvendo tanto o Estado do Paraná quanto a União e as empresas Citla e Pinho e Terras. Ao mesmo tempo, a pressão demográfica aumentou à medida que um grande número de colonos, vindos do Rio Grande do Sul e Santa Catarina, chegava à região Sudoeste do Paraná em busca de melhores condições de vida. O aumento populacional elevou também a tensão política. $\mathrm{O}$ surgimento de mais duas companhias colonizadoras, a Companhia Comercial e Agrícola Paraná (Comercial) e a Companhia Colonizadora Apucarana Ltda. (Apucarana), ligada ao grupo político vencedor das eleições de 1955, acirrou a concorrência com a Citla, atraindo mais migrantes sulistas. "Em novembro de 1950, o governo da União vendeu à Citla [Clevelândia Industrial e Territorial Ltda.] toda a gleba das Missões e parte da gleba Chopim. Poucos dias após vendia à Pinho e Terras 11,500 alqueires da própria gleba Missões. Vendia também 300,000 pinheiros à Companhia de Madeiras do Alto Paraná" (Wachowicz, 1995: 216).

Novas estradas foram abertas pela Citla e a Cango fazendo aumentar o fluxo de imigrantes sulistas que eram assentados, por um lado e surgir serrarias clandestinas, por outro. Os serradores, instalados como colonos, invadiam terras de pinheiral, retiravam a madeira e vendiam a terra, o que comprometeu as reservas nativas existentes. Era com tais reservas que a Citla contava para instalar uma indústria de celulose com capitais franceses. O projeto logo foi abandonado. Para recuperar o capital já investido, puseram terras à venda para os colonos através das imobiliárias Comercial e Apucarana.

Os colonos se viram em meio a disputas, ameaçados de perder as terras que haviam comprado e forçados a assinar notas promissórias como garantia de pagamento. $\mathrm{Na}$ inexistência de escritura legal, a posse insegura fazia com que desconfiassem da lisura do contrato, já que muitos acabaram tendo que pagar novamente pela mesma terra a sucessivos posseiros. Diante da recusa de muitos deles em assinar o contrato de compra e venda da terra, começa, em 1957, um conflito armado entre os colonos e 
os jagunços das companhias. Somente os comerciantes deram apoio direto à revolta dos colonos, uma aliança que praticamente selou a vitória destes últimos. De acordo com Brandenburg,

O levante decisivo envolveu 6 mil colonos na cidade de Francisco Beltrão, local onde o movimento adquiriu maior expressão. Os agricultores tomaram a cidade e exigiram "substituir o delegado de polícia, exonerar o promotor, transferir o juiz, retirar imediatamente as companhias da região e que aqueles que tivessem participado do movimento não fossem vítimas de perseguição" (Gomes, 1986: 100). Pressionado, o governador atendeu todas as condições dos revoltosos, entregando o comando da delegacia a um dos líderes locais mais expressivos e que dera apoio ao movimento. (Brandenburg, 1998: 81-82).

Na década de 1960, o Grupo Executivo de Terras para o Sudoeste do Paraná (GESOP) regulariza a titulação das terras e passa a controlar as serrarias clandestinas, cobrando taxas para iniciarem um horto florestal e o reflorestamento, segundo Steca e Flores (2002: 87). O território passará sentir, a partir dos anos de 1950, particularmente em 1953 e 1955, os sintomas perversos da expansão.

A ocorrência de fortes geadas abalou a economia e a sociedade paranaense, devido à queda acentuada da produção do café e, conseqüentemente, com a diminuição das receitas dele provenientes. A queda do emprego e da renda gera insegurança para a maioria da população. Cabe ressaltar ainda que a demanda por serviços públicos nos municípios recém ocupados aumentou consideravelmente, depois que foram atingidos pelas geadas. O problema se acentuou em períodos posteriores, agravando o quadro de vulnerabilidades ambientais. Como aponta Souza:

Além das dificuldades de comunicação entre as regiões norte e sul do estado (e o conseqüente esforço por parte do governo estadual no sentido de superá-las, ampliando, dessa forma, as possibilidades de escoamento da produção), nos anos posteriores alguns elementos novos contribuirão para colocar a economia cafeeira em crise e adentrar uma fase de decadência. Dentre eles Wachowicz (1995: 262) ressalta os seguintes: a) a ocorrência de geadas em 1963, 1964, 1966 e 1969; b) a política de erradicação de cafeeiros, com finalidade de diminuir a produção nacional; c) o incipiente desenvolvimento de um novo produto de grande aceitação internacional, a soja; $d$ ) o receio de ocorrência de novas geadas que prejudicassem a produção cafeeira, o que de fato, veio a ocorrer alguns anos mais tarde. (Souza, 2000: 21).

Em meio a esses acontecimentos, resistindo ao poder das colonizadoras, que se articularam com o latifúndio rural, um novo 
processo de ocupação da região se impôs. A ocupação econômica do espaço rural paranaense, diferentemente de outras regiões, vai contar com a participação de um novo ator, que ajuda a democratizar o acesso à propriedade da terra: o agricultor familiar. Porém, o processo de degradação do território se agrava.

\subsection{O processo de degradação no território paranaense}

A geada negra, de 1975, foi a maior já ocorrida no Paraná e opôs forte restrição ao padrão de ocupação econômica via fronteira aberta no espaço rural, dizimando grande parte das plantações de café da região norte do Paraná, provocando dispensa numerosa de mão-de-obra e, conseqüentemente, forte êxodo rural. Segundo Relatório do Ipardes (1993), foi reduzida em aproximadamente 1 milhão e 300 mil os residentes no espaço rural das áreas mais degradadas pela erosão, enquanto que no Estado do Paraná como um todo, no mesmo período, entre final dos 1970 e todo os 1980, a população residente no espaço rural reduziu em 1 milhão e 200 mil. Sai de cena o café, entra a soja e a carne nos anos de 1970, a partir da implantação de corredores de exportação, o que levou á especialização do Estado em algumas commodities agrícolas. Ao perder as condições anteriores de sustentabilidade, um novo ciclo de fronteira agrícola começa a surgir, com o plantio comercial da soja, e depois, com as crescentes perdas dos produtores de café, foram priorizados outros cultivos, como o do trigo, e a exploração pecuária.

Apesar de possuir uma estrutura agrária mais democrática, a desigualdade no acesso a espaços e recursos naturais é reforçada pela degradação ambiental do território. Isto porque, ao se orientar a economia paranaense para o mercado externo, os imperativos do mercado passam a exigir permanentemente maiores níveis de produtividade e rentabilidade agropecuária para que os agricultores se reproduzam enquanto tais, de acordo com as regras de reprodução características do capitalismo agrário brasileiro. Situação esta que dificultou sobremaneira o desenvolvimento da agricultura familiar em bases sustentáveis, fazendo com que o ritmo da expansão econômica nesse espaço rural condicionasse fortemente a relação da agricultura familiar com o meio ambiente. 
mecanização intensiva, que agravou dramaticamente os problemas de erosão e degradação dos recursos naturais. Isto levou os agricultores à utilização mais intensiva de insumos para suprir a fertilidade natural, assim acarretando desequilíbrios acentuados no meio ambiente. Esta lógica produtiva com maiores índices de mecanização, por sua vez, intensificou a degradação dos recursos naturais. As perdas médias de solo, devido aos processos de erosão hídrica mais expressivos, têm sido observados nos cultivos de batata (180 ton/ha/ano), café (25.6 ton/ha/ ano), sucessão trigo/soja (13.7 ton/ha/ano), algodão (13 ton/ha/ano) e milho (11 ton/ha/ano). Por sua vez, as perdas médias por erosão laminar nas terras agrícolas do Paraná chegam a 15.6 ton/ha/ano, o que pode significar 250'000.000 de toneladas de solos anuais erodidos em todo o Estado (Sabanés, 2002: 89).

Baseado nessa situação pode-se considerar que, apesar de possuir uma estrutura agrária mais democrática, a desigualdade no acesso a espaços e recursos naturais é reforçada pela degradação ambiental do território paranaense. $\mathrm{O}$ ritmo da expansão econômica nesse espaço rural revela o problema agrário-ecológico em sua dupla dimensão, primeiro, na sua dimensão econômica: os agricultores familiares se vêm obrigados a internalizar os custos ambientais e são permanentemente, por isso, impelidos a aumentar produtividade e rentabilidade agrícola. E em toda sua dimensão ambiental: obrigando o agricultor familiar do $\mathrm{Pa}-$ raná implementar práticas conservacionistas dos solos e das águas, mesmo com o foco da ação visando tão-somente a recuperação do rendimento e a rentabilidade das lavouras. A salvaguarda dos limites agroecossistemos tornou-se uma equação de altos custos sociais e ambientais face à perpetuidade como se reproduz a exploração intensiva via mecanização agrícola.

Evidenciou-se, então, um trade-off entre os custos ambientais a serem internalizados e as necessidades de reprodução socioeconômica imediata dos agricultores familiares daquela região, por causa da estreita vinculação com o mercado de commodities, que os impele a degradar ainda que sem itinerar. A exploração intensiva dos sistemas agrícolas convencionais aprofundou esse trade-off e, por conseguinte, leva a questionar se de fato ocorrerá a transição para uma agricultura ambientalmente mais sustentável na Região Sul do Brasil. Isto porque, do ponto de vista agrário-ecológico, novos conflitos surgem evidenciando a distância entre a maior democracia rural e a menor sustentabilidade ambiental do território. Resumidamente, em relação ao Paraná, podese se afirmar que: 
- A descentralização da política de terras e ação das empresas colonizadoras. Conflitos: Palmas (1857-1895), Contestado (1912-1916) e Revolta dos Colonos (1957).

- A organização das colônias, a partir de 1875 , pelo poder público, como empreendimentos de produtores associados, a fim de resolver problemas de abastecimento econômico regional.

- A lógica de apropriação econômica e ocupação social do território sucumbiu aos poucos aos interesses do Estado nacional associados com os do capital estrangeiro, com vista a ocupar a região de fronteira.

- O capital estrangeiro, depois de receber terras em doação, ocupava o território, desmatava-o, loteava-o e vendia os lotes aos colonos atraídos pelo governo estadual-federal.

- Tratou-se da lógica de preencher territórios vazios coadunada a uma concepção de fronteira baseada na exclusão do elemento nativo, tanto o homem quanto a mata, promovendo uma exclusão tanto social como ambiental.

- Na agricultura familiar mais desenvolvida do país, a da região Sul, continuou a predominar atividades agropecuárias que ficaram a reboque das oportunidades econômicas dominantes disponíveis, como a produção e exportação de grãos (milho e soja), apesar daquela região possuir um bom discernimento sobre os problemas ambientais ocasionados pela mecanização das lavouras.

- Por exigirem custos cada vez mais eficientes, os imperativos do mercado acabam limitando as alternativas em prol da sustentabilidade territorial -que possivelmente gerariam mais emprego e renda no longo prazo-e favorecendo a busca de maior produtividade e rentabilidade no curto prazo, o que enfraquece a agrobiodiversidade camponesa.

\section{Considerações finais}

A manutenção da lógica de apropriação privada de terras e a elevação contínua da produtividade dos solos a níveis jamais vistos são fatores que fazem com que o estabelecimento de políticas públicas self-specific de feitio agroambiental ou agroecológico não surta o efeito desejado no longo prazo e nem necessariamente seja passível de total êxito mesmo numa estrutura agrária mais democrática. Diante disso, considera-se imprescindível o auxílio de novas estratégias de ação da política pública voltadas ao for- 
talecimento da capacidade da agricultura familiar em superar problemas ambientais, levando em conta que a questão ambiental está na raiz do problema agrário brasileiro.

A natureza do processo de apropriação privada da terra no Brasil teve na alienação-destruição da biodiversidade sua função principal, porque, primeiro, atendeu exclusiva e plenamente aos interesses dos grandes proprietários rurais em detrimento dos interesses da sociedade e, segundo, mais importante ainda, porque fez da monocultura de fronteira aberta (ou móvel) o elo básico de acumulação capitalista. Dessa maneira, a instituição do espaço rural brasileiro não foi fruto de um processo clássico de expropriação camponesa como o europeu, já que as condições institucionais estavam dadas pela herança escravista e reiteradas pela aliança entre os proprietários de terras e o Estado nacional, isto é, propôs aqui neste texto que ela fosse entendida como uma motivação original: o processo de expropriação ambiental do território.

Nesse sentido, algumas das idéias expostas neste artigo podem ser resumidas para demarcar novos caminhos da agenda de pesquisas em torno das transformações agrário-ecológicas em áreas ou regiões rurais não apenas do Brasil, mas da América Latina como um todo. Primeiro, considerou-se a itinerância como principal forma ad perpetua de obtenção de rentabilidade agrícola, fazendo com que a degradação faça parte da lógica de apropriação territorial e o rentismo, da lógica de manutenção do status quo. Assim, a expropriação ambiental revela o modo como foram imprecisa e difusamente constituídos os laços entre o agrário e o ecológico no meio rural. Segundo, considera-se que muitas destas transformações redundaram em dificuldades para se entender o rural além do agrícola (enfoque setorial), cabendo vislumbrar um novo papel para a questão agrária, ecologizar o rural e redefinir sua crítica para a análise mais realista do desenvolvimento de uma agricultura sustentável. Terceiro, considerase que esta função problematizadora das transformações agrário-ecológicas no espaço rural propõe um olhar socioespacial particular acerca do velho antagonismo social entre pequena e grande propriedade e um olhar crítica sobre a transição para uma agricultura sustentável, que não se resume a adoção de práticas conservacionistas dos recursos naturais. É nesse contexto que se discute uma ecologia política para o agrário como uma questão agrário-ecológica, uma questão política radical.

A presença mais constante da agricultura familiar na estrutura agrária da Região Sul do Brasil abriu o horizonte de ação das 
políticas públicas. Porém, este horizonte deve ficar menos restrito à implementação da política agrícola e fundiária convencionais e passar a calcar-se em políticas territoriais re-configuradoras do agrário pelo ecológico. No caso da Região Sul do Brasil, mesmo com as relações de propriedade resultando de um processo diferenciado de ocupação do território, o problema da degradação ambiental não foi contornado e os limites da transição para uma agricultura sustentável estão colocados pelos imperativos do mercado exportador de grãos, que tornam as estratégias de reprodução socioeconômica da agricultura familiar ecologicamente redundantes. Em síntese, a questão ambiental é interpretada aqui como um fator estruturante do espaço rural à medida que o processo de apropriação privada de terras e a competição por espaços produtivos criam limites determinantes para o futuro agrário e ecológico dos territórios.

\section{Referências}

Brandebburg, Alfio (1998), "Colonos: subserviência e autonomia", en Angela Ferreira, Damasceno Duarte y Alfio Brandenburg (org.), Para pensar: outra agricultura, UFPR, Curitiba.

Brenner, Robert (1995), "Agrarian Class Structure and Economic Development in Pre-Industrial Europe", en T. H. Aston y C. H. E. Philpin (eds.), The Brenner Debate: Agrarian Class Structure and Economic Development in Pre-Industrial Europe, Cambridge University Press, Cambridge.

Cano, Wilson (1998), Desequilíbrios regionais e concentração industrial no Brasil, 1930-1995, $2^{\mathrm{a}}$ ed. rev. y aum., Unicamp, Campinas, SP.

Cano, Wilson (2002), Ensaios sobre a formação econômica regional do Brasil, Editora da Unicamp, Campinas, SP.

Checchia, Cristiane (2007), Terra e capitalismo: a questão agrária na Colômbia, 1848-1853, Alameda, São Paulo. 
Chonchol, Jaques (1996), Sistemas agrarios en América Latina: de la etapa prehispánica a la modernización conservadora, Fondo de Cultura Económica, México.

Delgado, Guilherme C. (2001), “Expansão e modernização do setor agropecuário no pós-guerra: um estudo de reflexão agrária”, Estudos Avançados, 15 (43), Instituto de Estudos Avançados-usp, São Paulo, pp. 157-172.

Garcia, Afrânio y Moacir Palmeira (2001), “Transformação agrária”, en Ignacy Sachs et al. (orgs.), Brasil: um século de transformações, Cia das Letras, São Paulo.

Graziano da Silva, José (1996), A nova dinâmica da agricultura brasileira, Unicamp, Campinas.

Ipardes (Instituto Paranaense de Desenvolvimento Econômico e Social) (1993), "Avaliação da estratégia global do ParanáRural”, Relatório, Curitiba.

Leff, Enrique (2006), Racionalidade ambiental: a reapropriação social da natureza, Civilização Brasileira, Rio de Janeiro.

Lourenço, F. A. (2001), Agricultura ilustrada: liberalismo e escravismo nas origens da questão agrária brasileira, Unicamp, Campinas.

Machado, Paulo P. (2004). Lideranças do Contestado: a formação e a atuação das chefias caboclas (1912-1916), Editora da Unicamp, Campinas.

Martínez-Alier, Joan (1994), De la economía ecológica al ecologismo popular, Icaria, Barcelona.

Martínez-Alier, Joan (2007), O ecologismo dos pobres: conflitos ambientais e linguagens de valoração, Contexto, São Paulo.

Moraes, Antônio Carlos Robert de (2005a), Meio ambiente e ciências humanas, $4^{\mathrm{a}}$ ed. ampl., Annablume, São Paulo. 
Moraes, Antônio Carlos Robert de (2005b), Território e história no Brasil, Annablume, São Paulo.

Pádua, José Augusto de (2002), Um sopro de destruição: pensamento político e crítica ambiental no Brasil escravista (1786-1888), Jorge Zahar Ed., Rio de Janeiro.

Rezende, Gervázio Castro de (2003), Estado, macroeconomia e agricultura, UFRGS-IPEA, Porto Alegre.

Romeiro, Ademar Ribeiro (1998), Meio ambiente e dinâmica de inovações na agricultura, Annablume, São Paulo.

Sabanés, Leandro (2002), Manejo sócio-ambiental de recursos naturais e políticas públicas: um estudo comparativo dos projetos "Paraná-Rural" e "Microbacias", tesis de maestría, Universidade Federal do Rio Grande do Sul, Porto Alegre.

Silva, Lígia Osório (2001), A fronteira e outros mitos, tese LivreDocência, Departamento de Política e História Econômica do Instituto de Economia, Universidade Estadual de Campinas, Campinas.

Silva, Lígia Osório (1996), Terras devolutas e latifúndio: efeitos da Lei de 1850, Unicamp, Campinas.

Souza, Marcelino (2000), Atividades não-agrícolas e desenvolvimento rural no Estado do Paraná, tesis de doctorado, Unicamp, Campinas.

Steca, Lucinéia Cunha y Mariléia Dias Flores (2002), História do Paraná: do século XVI à década de 1950, UEL, Londrina.

Toledo, Víctor M. (2002), "Agroecología, sustentabilidad y reforma agraria: la superioridad de la pequeña producción familiar, Agroecologia y Desenvolvimento Rural Sustentável, 3 (2), Porto Alegre, Rio Grande do Sul, pp. 27-36.

Wachowicz, Ruy C. (1995), História do Paraná, Vicentina, Curitiba. 
Recibido: 6 de abril de 2008. Reenviado: 9 de marzo de 2009. Aceptado: 18 de marzo de 2009.

Humberto Miranda Do Nascimento. É doutor em Economia Aplicada pelo Instituto de Economia da Universidade Estadual de Campinas (Unicamp), Estado de São Paulo, Brasil. Atualmente é Professor Doutor do Instituto de Economia da Universidade Estadual de Campinas (IE.Unicamp), Campinas, Brasil. Pesquisador do Centro de Estudos do Desenvolvimento Econômico (CEDE), no IE.Unicamp. Sua área de especialização é: desenvolvimento econômico, espaço e meio ambiente, com ênfase no desenvolvimento rural e territorial y sua linha de investigação atual é Dinâmica regional da agricultura brasileira. Seus últimos artigos publicados são: en coedición, "Geo-environmental Characterization and Occupation of the Beaches on the Islands of Tinhare and Boipeba, South Coast of the State of Bahia, Brazil", in: ICS200910th International Coastal Symposium, 2009, Lisboa, Journal of Coastal Research, SI 56, Lisboa, Proceedings of the 10th International Coastal Symposium, 2009. v. SI 56, pp. 1297-1300; en coedición, "Geo-environmental Characterization and Occupation of the Beaches on the Islands of Tinharé and Boipeba, South Coast of the State of Bahia, Brazil", in ICS2009 -10th International Coastal Symposium, 2009, Lisboa, Journal of Coastal Research, SI 56, Lisboa; Proceedings of the 10th International Coastal Symposium, 2009. v. SI 56, p. 1297-1300; "A convivência com o semi-árido e as transformações socioprodutivas na região do Sisal-Bahia: por uma perspectiva territorial do desenvolvimento rural”, Campo-Território, 6 (3), Universidade Federal de Uberlândia, Uberlândia, pp. 22-44 (2008). 